\title{
Goodness gracious great balls of fire
}

\author{
Natasha Kamal, ${ }^{1,2}$ Clara Chen, ${ }^{3}$ Alexander Ling, ${ }^{3}$ Thomas 0 'Donnell, ${ }^{4}$ Theo Heller $^{1}$
}

${ }^{1}$ Liver Disease Branch, National Institutes of Health, Bethesda, Maryland, USA

${ }^{2}$ Department of Internal Medicine, Mount Sinai Medical Center, New York, New York, USA

${ }^{3}$ Department of Radiology and Imaging Sciences, National Institutes of Health, Bethesda, Maryland, USA

${ }^{4}$ Digestive Disease Branch, National Institutes of Health, Bethesda, Maryland, USA

\section{Correspondence to}

Dr Natasha Kamal, kamal.natasha@gmail.com

Thomas O'Donnell passed away prior to publication of this paper.

\section{DESCRIPTION}

A 54-year-old caucasian man with a history of hypertension and traumatic splenectomy presented with an enlarged right inguinal lymph node. During the work-up, the patient received a contrast-enhanced CT scan of the chest, abdomen and pelvis that identified an enhancing $3 \times 3.5 \mathrm{~cm}$ mass in the region of the left kidney and multiple small nodules throughout the mesentery, above the liver and adjacent to the sigmoid colon. These findings were related to metastatic renal cell carcinoma. A complete metastatic work-up was ordered including a Tc-labelled denatured red blood cell (RBC) scan.

A Tc-labelled heat denatured RBC SPECT scan was performed because the clinician had a high suspicion for splenosis. Splenosis is the dissemination of small splenic foci $(1-3 \mathrm{~mm})$ after splenic injury. ${ }^{1}$ Most commonly, splenosis occurs near the splenic fossa. ${ }^{2}$ Both Tc-labelled heat denatured RBC SPECT and Tc-sulphur colloid scans can be used to detect splenosis. The former is more specific than the latter because otherwise in normal patients, splenic tissue takes up greater than $90 \%$ of damaged RBCs but only $10 \%$ of injected sulphur colloid. $^{3}$
In figure 1, the two largest splenules are on the anterior surface of the liver (figure $1 \mathrm{~A}-\mathrm{C}$ ) and in the rectosigmoid region (figure 1G-I). There is no uptake of denatured RBCs in the kidney (figure 1D,F) suggesting that $3 \times 3.5 \mathrm{~cm}$ left renal mass seen previously on contrast-enhanced CT was not of splenic origin and represented renal cell carcinoma.

\section{Learning points}

Splenosis is the dissemination of small foci of splenic tissue usually following splenic trauma.

- Splenosis may mimic metastatic lesions on contrast-enhanced CT.

- A Tc-labelled heat denatured RBC SPECT scan can be used to differentiate splenules from primary lesions.

\section{Competing interests None.}

Patient consent Obtained.

Provenance and peer review Not commissioned; externally peer reviewed.

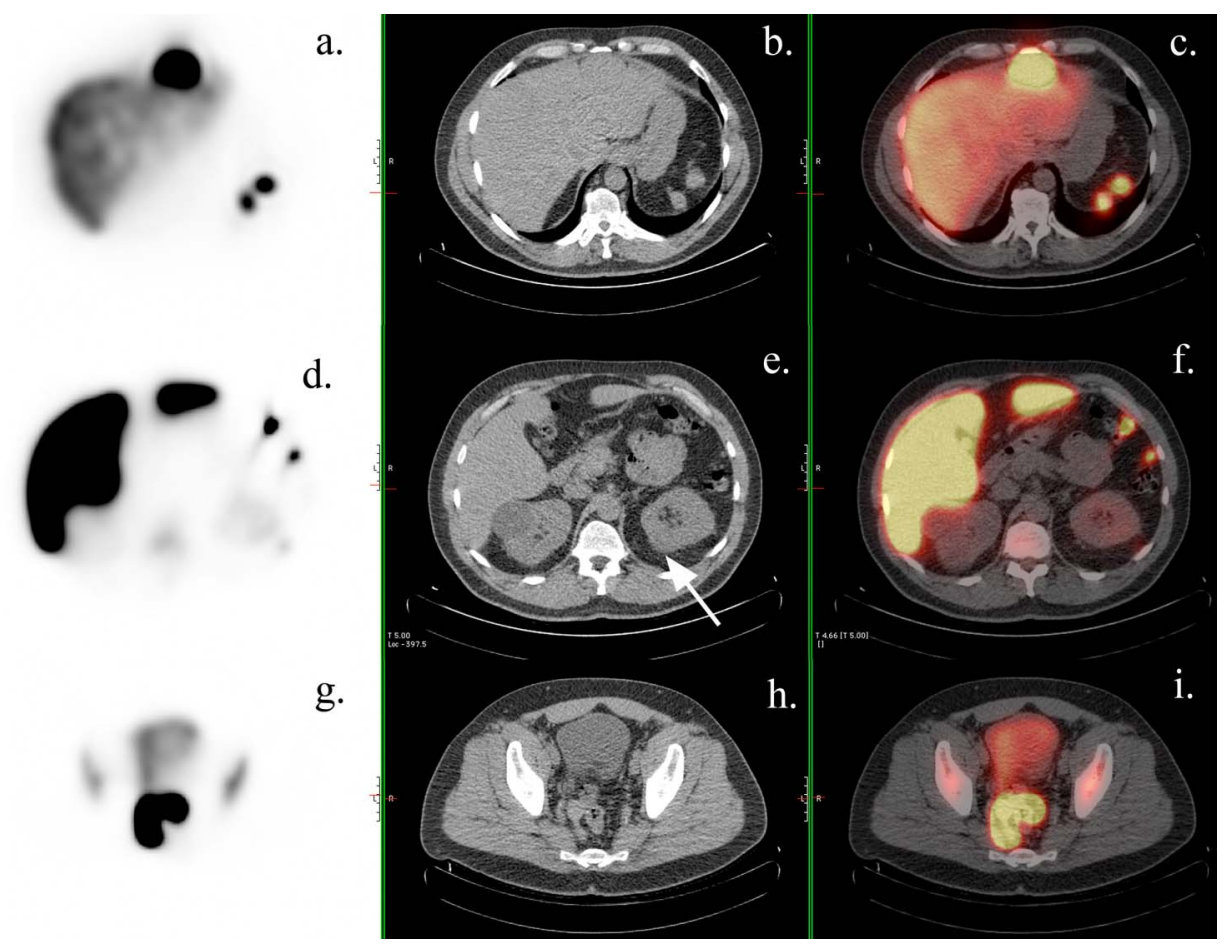

To cite: Kamal N, Chen $C$, Ling $A$, et al. BMJ Case Reports Published online: [please include Day Month Year] doi:10.1136/bcr-2012007903
Figure 1 (A) Transverse Tc-labelled denatured red blood cell (RBC), attenuation CT (B) and fused SPECT CT (C) images of the upper abdomen demonstrating a lesion on the anterior surface of the left lobe of the liver with two additional lesions in the splenic fossa. (D) Transverse Tc-labelled denatured RBC, attenuation CT (E) and fused SPECT $\mathrm{CT}$ (F) images scan of the mid-abdomen demonstrating two mesenteric lesions. The $\mathrm{CT}$ also shows a right renal cyst and a nodule adjacent to the left kidney. (G) Transverse Tc-labelled denatured RBC, attenuation $\mathrm{CT}(\mathrm{H})$ and fused SPECT CT (I) images of the pelvis demonstrating lesions adjacent to the sigmoid colon. 


\section{REFERENCES}

1 Brown JD, Kwee $S$. Pararenal splenosis encountered during the evaluation of suspected pheochromocytoma. Am J Med Sci 2010;340:424-6.
2 Turk CO, Lipson SB, Brandt TD. Splenosis mimicking a renal mass. Urology 1988;31:248-50

3 Fremont RD, Rice TW. Splenosis: a review. South Med J 2007:100:589-93.

Copyright 2013 BMJ Publishing Group. All rights reserved. For permission to reuse any of this content visit http://group.bmj.com/group/rights-licensing/permissions.

BMJ Case Report Fellows may re-use this article for personal use and teaching without any further permission.

Become a Fellow of BMJ Case Reports today and you can:

Submit as many cases as you like

- Enjoy fast sympathetic peer review and rapid publication of accepted articles

- Access all the published articles

- Re-use any of the published material for personal use and teaching without further permission

For information on Institutional Fellowships contact consortiasales@bmjgroup.com

Visit casereports.bmj.com for more articles like this and to become a Fellow 